\title{
First record of Unibarra paranoplatensis Suriano \& Incorvaia, 1995 (Dactylogyridae: Monogenea) on Sorubim lima (Siluriformes: Pimelodidae) from Brazil
}

\author{
Primeiro registro de Unibarra paranoplatensis Suriano \& Incorvaia, 1995 (Dactylogyridae: Monogenea) \\ em Sorubim lima (Siluriformes: Pimelodidae) do Brasil
}

Luciano Pereira de Negreiros $^{1 *}$ (D); Marcos Sidney Brito Oliveira² ${ }^{\text {(D); }}$ Marcos Tavares-Dias ${ }^{2}$

\begin{abstract}
${ }^{1}$ Programa de Pós-graduaçáo Rede de Biodiversidade e Biotecnologia da Amazônia Legal - PPG-BIONORTE, Universidade Federal do Amapá - UNIFAP, Macapá, AP, Brasil

${ }^{2}$ Empresa Brasileira de Pesquisa Agropecuária - EMBRAPA, Macapá, AP, Brasil
\end{abstract}

Received November 29, 2018

Accepted December 17, 2018

\begin{abstract}
The aim of this study was to report the first occurrence of Unibarra paranoplatensis Suriano \& Incorvaia, 1995 on Sorubim lima Bloch \& Schneider, 1801 from Brazil. On the gills of S. lima, U. paranoplatensis presented similar morphological and morphometric features to those described for conspecifics infesting Zungaro zungaro Humboldt, 1921 except the length, which was higher in the present study, as well as ventral bar shape that was V-shaped open, and with the upper and lower end of the rod relatively sinuous. This study expands the geographic distribution of U.paranoplatensis to Brazil, a parasite that has a wide occurrence across South America.
\end{abstract}

Keywords: Amazon, freshwater fish, helminth, Monogenea, parasite.

\section{Resumo}

O objetivo deste estudo foi relatar a primeira ocorrência de Unibarra paranoplatensis Suriano \& Incorvaia, 1995 em Sorubim lima Bloch \& Schneider, 180 do Brasil. Nas brânquias de S. lima do Rio Acre, estado do Acre (Brasil), $U$. paranoplatensis apresentou características morfológicas e morfométricas similares àquelas descritas para Zungaro zungaro Humboldt, 1921; com exceção do comprimento que foi maior no presente estudo e formato da barra ventral que foi em forma de $\mathrm{V}$ aberto, com a extremidade superior e inferior da barra relativamente sinuosa. Este estudo amplia a distribuiçáo geográfica de $U$. paranoplatensis para o Brasil, um parasito com distribuição na América do Sul.

Palavras-chave: Amazônia, peixe de água doce, helminto, Monogenea, parasito.

Monogenea Van Beneden, 1858 is a taxon strictly parasitic with monoxenic life cycle that occur mainly on gills or body surface of fish hosts. In fishes from South America Monogenea is the most specious group of ectoparasites, with 835 species and of these 471 were described in fishes from Brazil. Dactylogyridae species are the most abundant family in continental waters of South America (LUQUE et al., 2017). The genus Unibarra Suriano \& Incorvaia, 1995 is monoespecific Unibarra paranoplatensis Suriano \& Incorvaia, 1995, which was described in the gills from Zugaro zungaro Humboldt, 1821 is found in Pimelodus maculatus (Argentina); Aguarunichthys torosus (Peru), with geographic distribution in three countries of South America (Figure 1), in Amazon, Orinoco, Paraná and Parnaiba river basins (SURIANO \& INCORVAIA, 1995; COHEN et al., 2013; MENDOZA-PALMERO et al., 2015). However, this monogenean species has not been reported

*Corresponding author: Luciano Pereira de Negreiros. Universidade Federal do Amapá - UNIFAP, Rod. Juscelino Kubitschek, Km 2, Jardim Marco Zero, CEP 68903-419, Macapá, AP, Brasil. e-mail: luciano.negreiros@ifac.edu.br in Sorubim lima Bloch \& Schneider, 1801. This study is the first record of $U$. paranoplatensis in S. lima from Brazil.

Thirteen specimens of S. lima were collected in June 2017 in the Acre River basin $\left(10^{\circ} 1^{\prime} 59.53^{\prime \prime} S 67^{\circ} 52^{\prime} 4.93^{\prime \prime} \mathrm{O}\right)$, municipality of Rio Branco, State of Acre, Brazil (Figure 1). Live hosts were taken from field to the Laboratory of Aquiculture of the Federal Institute of Education, Science and Technology of Acre, in Rio Branco city, where the fish were euthanized and the gills immediately removed and placed in vials containing heated water $60{ }^{\circ} \mathrm{C}$, for collection of monogeneans. Later, the gills were fixed in 5\% formalin during $24 \mathrm{~h}$, preserved in 70\% ethyl alcohol and analyzed. For the study of haptoral and reproductive hard parts, three specimens were mounted in Hoyer medium for the study of their structures (EIRAS et al., 2006). Ecological terminology follows Bush et al. (1997).

All procedures involving animals were authorized by the Instituto Chico Mendes para Conservação da Biodiversidade (SISBIO, No 60899-1) and were strictly according to the protocols and 


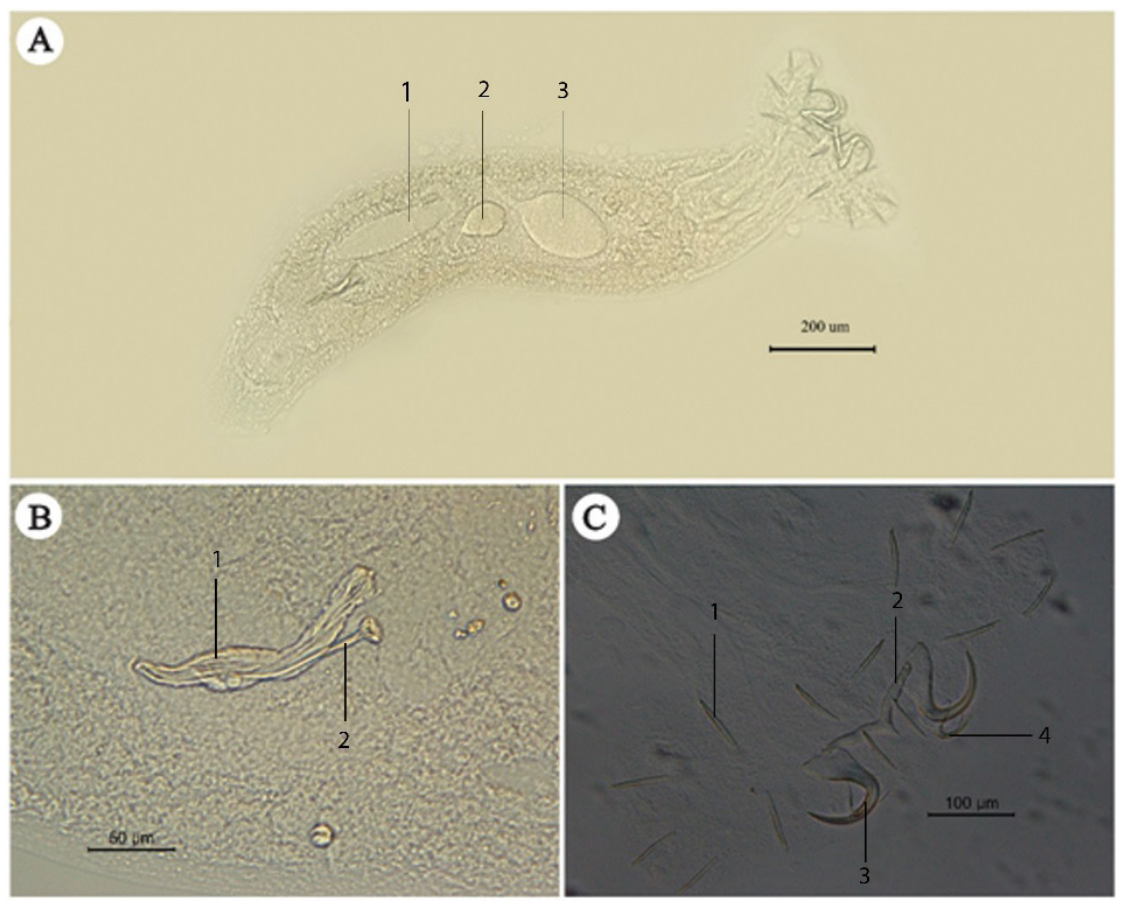

Figure 1. Unibarra paranoplatensis in Sorubim lima from the Acre River, in Brazil with Receptacle seminal (1), Seminal vesicule (2), Ovary (3) (A); Male Copulatory Organ (2), with Accessory piece (1) (B) and Haptor with hooks similar (1), transverse ventral bar (2), Anchor ventral (3), Anchor dorsal (4) (C).

rules of the Committee on Ethics of Animal Use of the Embrapa Amapá (Protocol: No 002-CEUA-CPAFAP). Voucher specimen was deposited in the Coleção Cientifica de Fauna do Amapá (CCFA) do Instituto de Pesquisas Cientificas e Tecnológicas do Estado do Amapá (IEPA), Macapá, Amapá State (Brazil).

Morphological and morphometric analyses were performed using a computerized image analysis system with differential interference contrast (LAS 3.8, LEICATM). Measurements, all in micrometers, represent straight-line distances between extreme points of the structures measured and are expressed as mean and range (in parentheses) (Table 1). The terminology specific to Unibarra fallows Suriano \& Incorvaia (1995).

Unibarra paranoplatensis Suriano \& Incorvaia, 1995 (Figure 2)

\section{Taxonomic summary}

Host: Sorubim lima Bloch \& Schneider, 1801

Locality: Acre River, Acre State, Brazil (09 59’05.53” S, $67^{\circ} 49^{\prime} 16.54$ " O)

Voucher number: 155 (CCFA)

Prevalence: 23\% (3 infected fish 13 examined fish), mean intensity of infection: 1 parasite per infected host.

\section{Remarks}

Unibarra paranoplatensis is known to infect $Z$. zungaro; Pimelodus maculatus Lacépede, 1803 (SURIANO \& INCORVAIA, 1995); Pimelodus albicans Valenciennes, 1840 (GUTIÉRREZ, 2001) and Aguarunichthys torosus Stewart, 1986

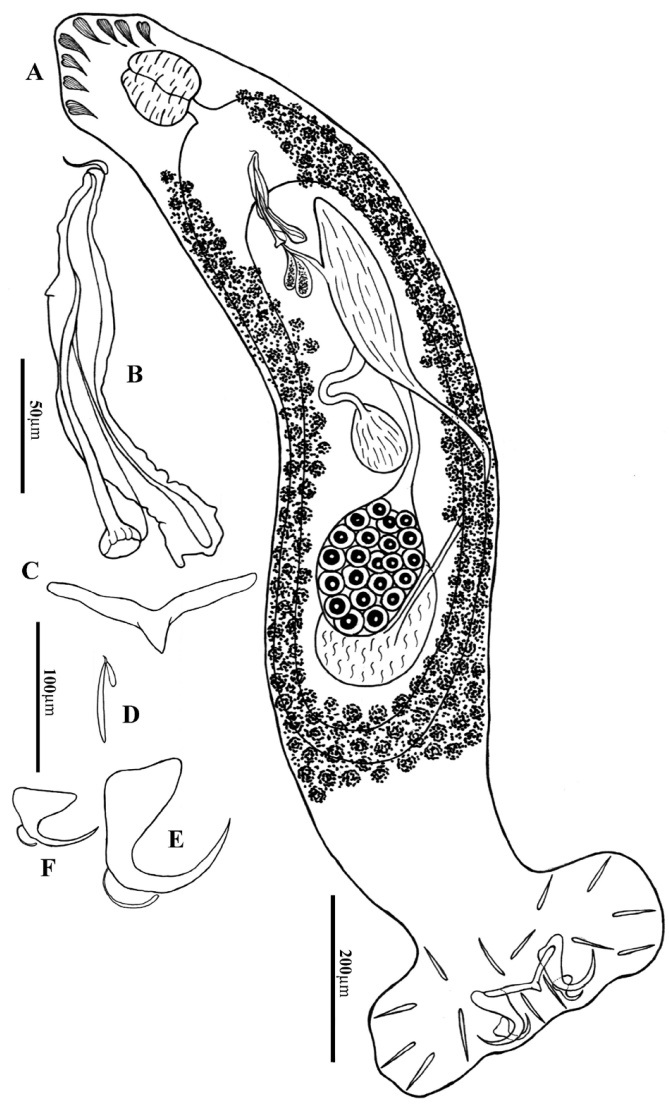

Figure 2. Unibarra paranoplatensis, parasite of gills of Sorubim lima from the Acre River, Brazil. A - composite drawing, ventral view; B - male copulatory organ, dorsal view; C - ventral bar; D - hook pairs 1 to 7; E - ventral anchor; F - dorsal anchor. 


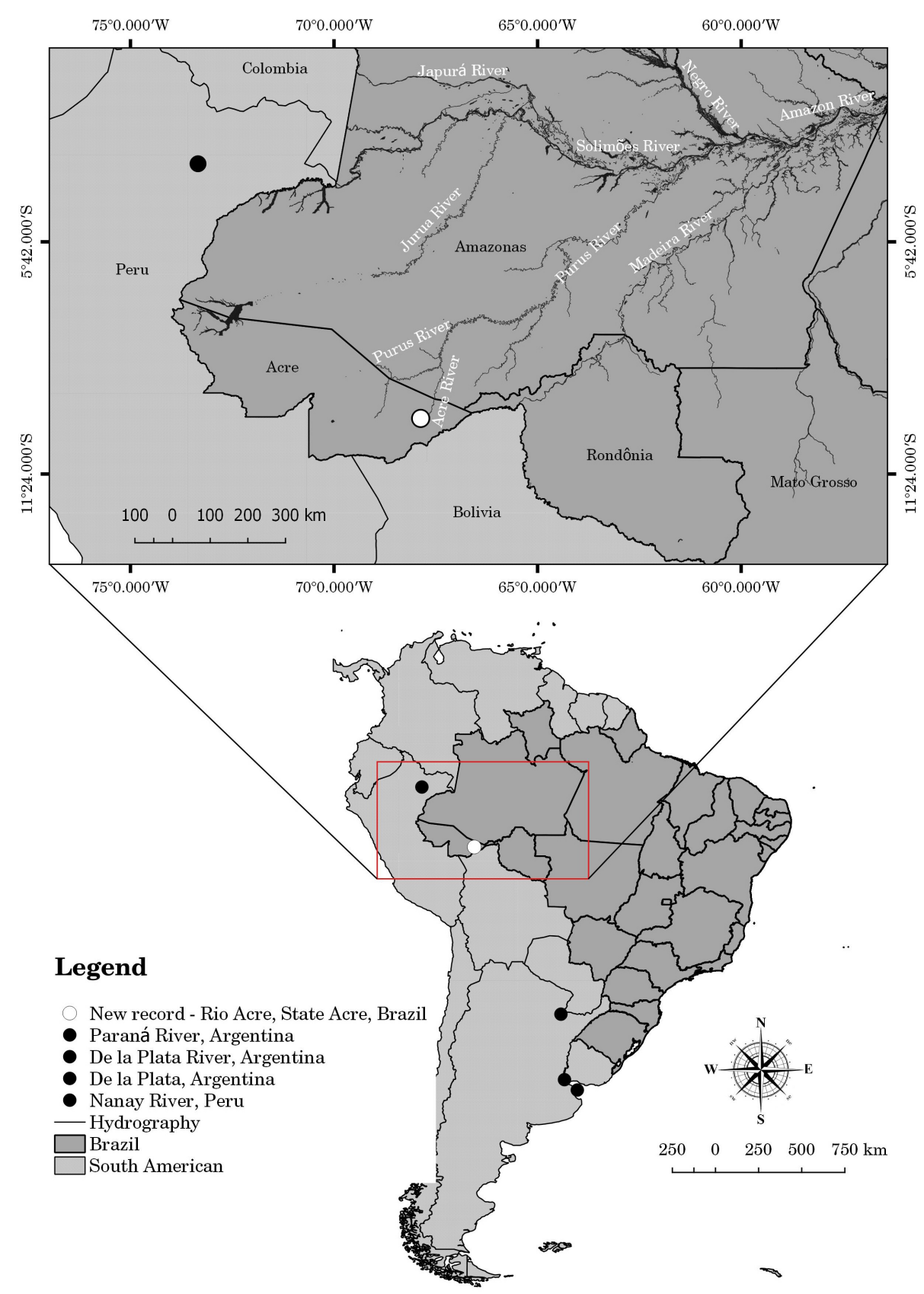

Figure 3. Geographic distribution of Unibarra paranoplatensis in South America.

(MENDOZA-PALMERO et al., 2015), and have distribution in pimelodid fish from the South America (Figure 1).

Unibarra paranoplatensis of S. lima presented similar morphology to described for cospecific infesting $Z$. zungaro. Presence of a single haptoral transverse bar (ventral), the hooklets similar in size and shaped (Figure 3C), absence of eyespost, conspicuous filament which connects the base of the male copulatory organ sclerotized, tubular with variable accessory piece, seminal vesicle a dilatation of the vas deferens; two prostatic reservoirs (Figure 3A) and similar male copulatory organ (Figure 3B) and two pairs of anchors (Figure 3C). However, the ventral bar was longer in the specimens of the present study, as well as the higher vaginal canal
(Table 1). In addition, the morphology of the ventral bar has an open $\mathrm{V}$ shape with the superior and inferior extremity relatively (Figure 3C), while for $U$. paranoplatensis from $Z$. zungaro there is the presence of a transverse ventral bar and vaginal canal longer to be less, which are not a characters that supports the description of a new species, since it can be caused by intraspecific variation of this structure, possibly due to changes associated with the host biology or parasite features. This is the only species described for the Unibarra genus and its main characteristic is the haptor with one transverse haptoral bar and two pairs of hamuli (anchors) (SURIANO \& INCORVAIA, 1995), confirming that the species of the present study is similar to $U$.paranoplatensis. 
Although S. lima have distribution in Amazon, Paraná and Parnaíba river basins (Brazil), this is first report of $U$. paranoplatensis for host from the Brazil, more specifically from Acre River, the Amazon basin.

Table 1. Morphometric comparison of Unibarra paranoplatensis $(\mathrm{N}=3)$, from Zungaro zungaro and Sorubim lima $(\mathrm{n}=13)$.

\begin{tabular}{lcc}
\hline \multicolumn{1}{c}{ Measurements } & $\begin{array}{c}\text { Zungaro zungaro } \\
\text { (Type host) }\end{array}$ & $\begin{array}{c}\text { Sorubim lima } \\
\text { (Present study) }\end{array}$ \\
\hline Body long & $2500(1250-2900)$ & $2095(2070-2120)$ \\
Greatest width & $560(320-578)$ & $370(307-371)$ \\
Pharynx width & $175(70-183)$ & $134(124-144)$ \\
Male copulatory organ & $215(153-230)$ & $149(146-151)$ \\
Accessory piece length & $208(135-210)$ & $167(165-168)$ \\
Vaginal canal long & $75(70-77)$ & $159(140-178)$ \\
Posteromedial process & $33(23-35)$ & $25(23-25)$ \\
Ventral bar & $110(108-113)$ & $165(164-167)$ \\
Ventral anchor & & \\
$\quad$ A & $80(78-105)$ & $71(70-73)$ \\
B & $88(35-90)$ & $52(49-53)$ \\
C & $20(14-25)$ & $26(25-28)$ \\
$\quad$ D & $55(34-57)$ & $63(61-64)$ \\
Dorsal anchor & & \\
A & $32(30-35)$ & $32(30-34)$ \\
B & $35(32-36)$ & $32(30-34)$ \\
C & $12(11-13)$ & $13(11-14)$ \\
D & $34(30-37)$ & $34(33-34)$ \\
Hook 1-7 & $65(61-70)$ & $68(60-74)$ \\
\hline A d &
\end{tabular}

A: distance from tip of superficial root to curve of de blade; B: distance from superficial root - deep notch to curve of the blade; C: length of superficial root; D: distance from tip of blade to curve of blade.

\section{Acknowledgements}

M. Tavares-Dias was granted a Research Fellowship (\# 303013/2015-0) from the National Council for Scientific and Technological Development (CNPq, Brazil).

\section{References}

Bush AO, Lafferty KD, Lotz JM, Shostak AW. Parasitology meets ecology on its own terms: Margolis et al. revisited. J Parasitol 1997; 83(4): 575583. http://dx.doi.org/10.2307/3284227. PMid:9267395.

Cohen SC, Justo MC, Kohn A. South American Monogenoidea Parasites offishes, amphibians and reptiles. Rio de Janeiro: Oficina de Livros; 2013.

Eiras JC, Takemoto RM, Pavanelli GC. Métodos de estudo e técnicas laboratoriais em parasitologia de peixes. Maringá: Eduem; 2006.

Gutiérrez PA. Monogenean community structure on the gills of Pimelodus albicans from Río de la Plata (Argentina): a comparative approach. Parasitology 2001; 122(4): 465-470. http://dx.doi.org/10.1017/ S003118200100748X. PMid:11315180.

Luque JL, Pereira FB, Alves PV, Oliva ME, Timi JT. Helminth parasites of South American fishes: current status and characterization as a model for studies of biodiversity. J Helminthol 2017; 91(2): 150-164. http:// dx.doi.org/10.1017/S0022149X16000717. PMid:27855726.

Mendoza-Palmero CA, Blasco-Costa I, Scholz T. Molecular phylogeny of Neotropical monogeneans (Platyhelminthes: Monogenea) from catfishes (Siluriformes). Parasit Vectors 2015; 8(1): 164. http://dx.doi.org/10.1186/ s13071-015-0767-8. PMid:25890068.

Suriano MS, Incorvaia IS. Ancyrocephalid (Monogenea) parasites from siluriform fishes from the Paranean-Platean ichthyogeographical province in Argentina. Acta Parasitol 1995; 40(3): 113-124. 